\title{
Synthesis of Novel Polyhydroxylated Quinolizidines: Ring Expanded Analogs of Glycosidase Inhibitory Indolizidines
}

\author{
William H. Pearson* and Erik J. Hembre
}

Department of Chemistry, The University of Michigan, Ann Arbor, MI 48109-1055

\begin{abstract}
Two polyhydroxylated quinolizidines, $(1 R, 2 R, 3 R, 9 S, 9 \mathrm{a} R)-1,2,3,9$-tetrahydroxyquinolizidine 9 and $(1 R, 2 R, 3 R, 9 R, 9 \mathrm{a})-1,2,3,9-$ tetrahydroxyquinolizidine 10 , have been synthesized by the reductive double cyclization of $15 \alpha$ and $15 \beta$. Quinolizidine 9 can be viewed either as a ring expanded analog of 6-epicastanospermine or of 8episwainsonine, while 10 is a ring expanded analog of 1,6,8a-triepicastanospermine or of 8a-episwainsonine.
\end{abstract}

Polyhydroxylated alkaloids such as castanospermine 1, swainsonine 2, deoxynojirimycin $\mathbf{3}$, deoxymannojirimycin 4 , alexine 5 , and their derivatives have attracted considerable interest in recent years due to their potent activity as glycosidase inhibitors. ${ }^{1}$ Further interest in this class of compounds has been generated by their wide range of pharmacological activity, including anti-viral, anti-HIV, anti-cancer, antifeedant, and immunoregulatory activity. $1,2,3$<smiles>O[C@H]1CN2CC[C@@H](O)[C@H]2[C@@H](O)[C@H]1O</smiles>

Castanospermine 1<smiles>O[C@H]1CN2CCC[C@H](O)[C@H]2[C@@H]1O</smiles>

Swainsonine

2<smiles>OC[C@H]1NC[C@@H](O)[C@H](O)[C@H]1O</smiles>

Deoxynojirimycin 3<smiles>OC[C@H]1NC[C@@H](O)[C@H](O)[C@H]1O</smiles>

Deoxymannonojirimycin<smiles>OC[C@H]1[C@@H](O)[C@H](O)[C@H]2[C@@H](O)CCN12</smiles>

4
Alexine

5<smiles>OC(O)C[C@@]12CN(CCCC1O)[C@@H](O)[C@@H](O)[C@@H]2O</smiles>

7<smiles>OC[C@H]1[C@@H](O)[C@H](O)[C@@H](O)[C@@H]2[C@H](O)CCCN21</smiles><smiles>O[C@H]1C[C@H](O)N2CCC[C@@H](O)[C@@H](C2)[C@@H]1O</smiles><smiles>O[C@H]1C[C@H](O)N2CCC[C@@H](C2)[C@@H]1O</smiles>

Considerable effort has been put forth by a number of researchers to investigate the structure-activity relationships of the polyhydroxylated indolizidines, resulting in the synthesis of many of the stereoisomers of castanospermine 1 and swainsonine 2 for biological evaluation. 2,3 Stereoisomers of polyhydroxylated pyrrolizidines (e.g. alexine 5 and australine) as well as ring contracted versions of polyhydroxylated indolizidine alkaloids have also been prepared and in some cases evaluated for inhibitory activity. ${ }^{4}$ Few 
reports of ring expanded analogs of polyhydroxylated indolizidines have appeared. Grandig and Stütz et al prepared the castanospermine homologue $(1 R, 2 R, 3 S, 9 S, 9 \mathrm{a} R)-1,2,3,9$-tetrahydroxyquinolizidine 7 , which has shown $\beta$-glucosidase inhibitory activity. ${ }^{5}$ Liu et al prepared the hydroxymethyl substituted quinolizidine 8 , which strongly inhibits $\alpha$-glucosidase I from pig kidney. ${ }^{6}$ To further explore the chemistry of this family of compounds we have undertaken the synthesis the polyhydroxylated quinolizidines 9 and 10 . Compound 9 closely resembles D-mannopyranose. It can be viewed as a ring expanded analog of the naturally occuring amyloglucosidase inhibitor 6-cpi-castanoperminc 8,3 or as a hydroxymethine ring expanded version of 8-episwainsonine. ${ }^{2}$ Similarily, 10 can be viewed as a ring expanded analog of 1,6,8a-triepicastanospermine, or of 8a-epi-swainsonine. ${ }^{2}$

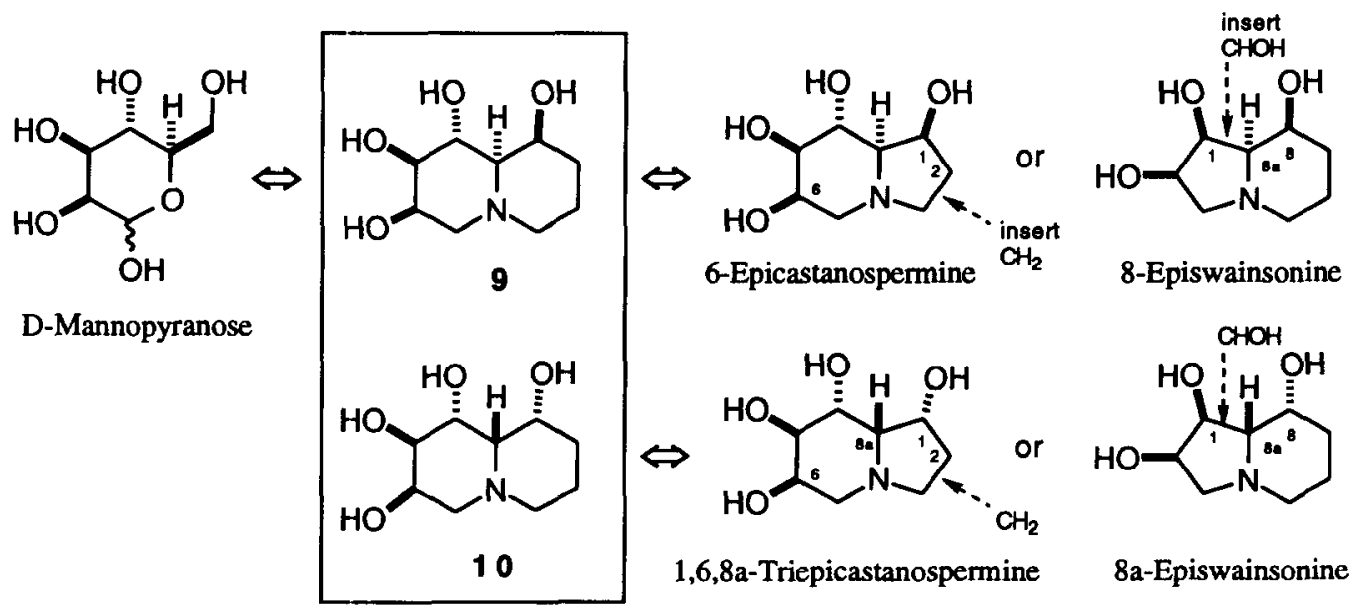

The key step in the synthesis of $\mathbf{9}$ and $\mathbf{1 0}$ is the efficient formation of the quinolizidine ring system via a reductive double alkylation of an azido-epoxide that possesses an $\omega$-leaving group (Scheme 1). We $\mathrm{Cc}^{4 \mathrm{7}}$ and others ${ }^{4 a, d, 8}$ have previously employed a similar strategy to assemble pyrrolizidine and indolizidine ring systems.

(RO)

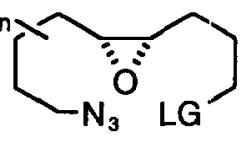

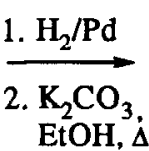

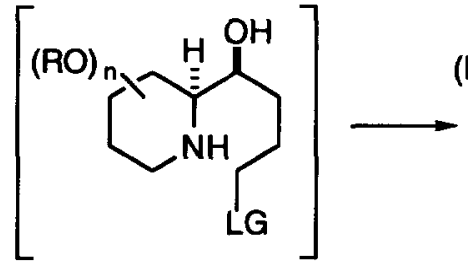

Scheme 1
(RO)<smiles>O[C@H]1CCCN2CCCCC[C@H]12</smiles>

Our synthesis began with 2,3,4-tri-O-benzyl-D-arabinopyranose 11, which was prepared from D-arabinose in three steps according to Fletcher's procedure (Scheme 2) ${ }^{9}$ Wittig olefination of 11 with the chloro-substituted phosphonium salt $12^{10}$ selectively yielded the (Z)-chloroalkenol 13 in $71 \%$ yield, which was then converted to azide 14 in $84 \%$ yield using the Mitsunobu method.11 Epoxidation of 14 with $m$-CPBA produced an inseparable mixture of epoxides $15 \alpha$ and $15 \beta(2.5: 1$ ) in $88 \%$ ( $\alpha$ and $\beta$ refer to the orientation of 
the epoxide oxygen). Reduction of the mixture of azido-epoxides $15 \alpha / 15 \beta$ to amino-epoxides $16 \alpha / 16 \beta$ without debenzylation was accomplished under mild Pd-catalyzed hydrogenolysis conditions. The amino compounds $16 \alpha / 16 \beta$ were not purified, but were heated in refluxing ethanol containing $\mathrm{K}_{2} \mathrm{CO}_{3}$ to produce a mixture of quinolizidines 17 and $18(2.5: 1)$ in $65 \%$ from 15 $\alpha 15 \beta$. Compounds 17 and 18 separated $\left(\mathrm{SiO}_{2}\right)$ and their stereochemistries were assigned by examination of ${ }^{1} \mathrm{H}$ NMR coupling constants. ${ }^{12}$ The stereochemistry of the major isomer 17 implies that $15 \alpha$ is the major product of the epoxidation reaction. Debenzylation of 17 and 18 was carried out under more rigorous Pd-catalyzed hydrogenolysis conditions to yield respectively $(1 R, 2 R, 3 R, 9 S, 9 \mathrm{a} R)-1,2,3,9$-tetrahydroxyquinolizidine 9 in $99 \%$ and $(1 R, 2 R, 3 R, 9 R, 9 \mathrm{a} S)-1,2,3,9$-tetrahydroxyquinolizidine 10 in $92 \% .13$

Screening for glycosidase inhibitory activity is underway and will be reported with a full account of this work.<smiles>OC1OC[C@@H](O)[C@@H](O)[C@H]1O</smiles>

D-Arabinose<smiles>OC1OC[C@@H](OCc2ccccc2)[C@H](OCc2ccccc2)[C@@H]1OCc1ccccc1</smiles>

11

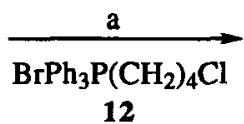
12<smiles>OC[C@H](OCc1ccccc1)[C@@H](OCc1ccccc1)[C@H](Br)C=CCCCCl</smiles>

13 (71\%)

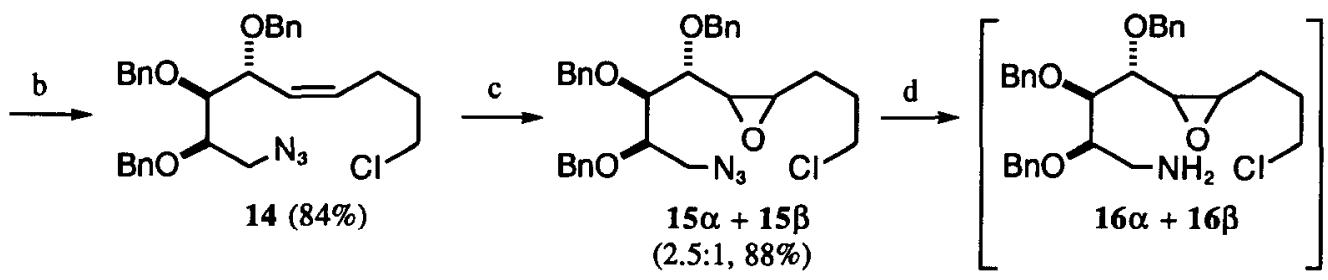
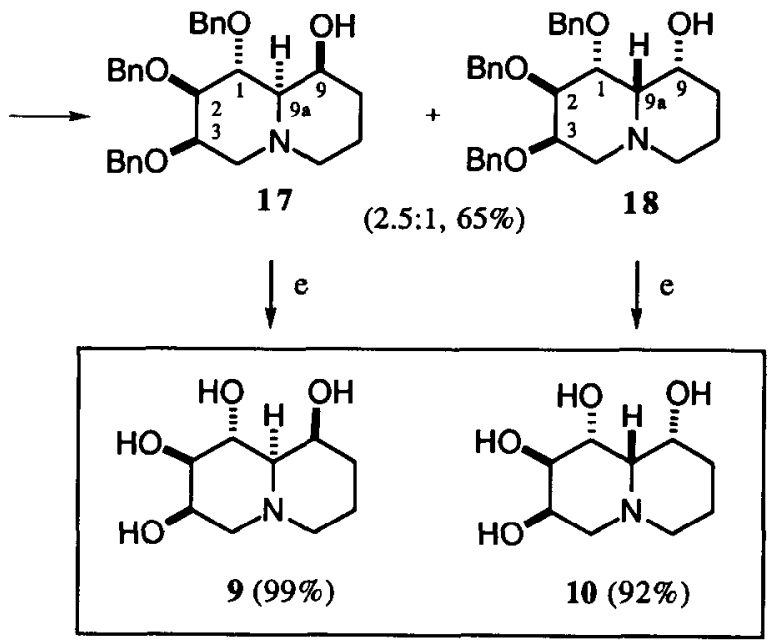

Scheme 2: (a) 2.5 eq. $12+2.5$ eq. KHMDS, THF, $0^{\circ} \mathrm{C}, 30 \mathrm{~min}$., then add 11 as a soln. in $\mathrm{CH}_{2} \mathrm{Cl}_{2}$ at $-78{ }^{\circ} \mathrm{C}$, and warm slowly to r.t., 5 h. (b) $13+1.2$ eq. $\mathrm{PPh}_{3}$ in $\mathrm{PhH}$, add 1.2 eq. $\mathrm{HN}_{3}$ as a $1.2 \mathrm{M}$ soln in $\mathrm{PhH}$, cool to $0^{\circ} \mathrm{C}$, add 1.2 eq. $\mathrm{DEAD}$ dropwise, warm to r.t. for $30 \mathrm{~min}$. (c) 2 eq. $m$-CPBA, $\mathrm{CH}_{2} \mathrm{Cl}_{2}$, $0^{\circ} \mathrm{C}$, then warm to r.t. for $12 \mathrm{~h}$. (d) $10 \%$ w/w of $10 \% \mathrm{Pd} / \mathrm{C}, \mathrm{Et}_{2} \mathrm{O} / \mathrm{EtOH}(2: 1), \mathrm{H}_{2}$ (1 atm), r.t. for $24 \mathrm{~h}$; filter off $\mathrm{Pd} / \mathrm{C}$, then 6 eq. $\mathrm{K}_{2} \mathrm{CO}_{3}, \mathrm{EtOH}$, reflux, 24h. Separate diastereomers. (c) $45 \% \mathrm{w} / \mathrm{w}$ of $10 \% \mathrm{Pd} / \mathrm{C}$, $2 \% \mathrm{HCl}$ in $\mathrm{MeOH}, \mathrm{H}_{2}(45 \mathrm{psi})$, r.t., $48 \mathrm{~h}$.

Acknowledgement We thank the National Institutes of Health (GM-35572) for support of this research. 


\section{NOTES AND REFERENCES}

1. For reviews of glycosidase inhibitors see: a) Elbein, A. D., Ann. Rev. Biochem, 1987, 56, 497-534. b) Elbein, A. D., FASEB J., 1991, 5, 3055-63.

2. For structure-activity relationships of swainsonine analogs see: a) Cenci di Bello, I.; Fleet, G.; Namgoong, S. K.; Tadano, K.; Winchester, B. Biochem. J., 1989, 259, 855-861. b) Winkler, D. A.; Holan, G. J. Med. Chem., 1989, 32, 2084-2089. c) Elbein, A. D.; Szumilo, T.; Sanford, B. A.; Sharpless, K. B.; Adams, C. Biochemisty, 1987, 26, 2502-2510.

3. For structure-activity relationships of castanospermine analogs see: a) Burgess, L.; Henderson, I.; Tetrahedron. 1992, 48, 4045-4066. b) Winchester, B. G.; Cenci di Bello, I.; Richardson, A. C.; Nash, R. J.; Fellows, L. E.; Ramsden, N. G.; Fleet, G. Biochem. J., 1990, 269, 227-231.

4. a) Carpenter, N. M.; Fleet, G. W. J.; Cenci di Bello, I.; Winchester, B.; Fellows, L. E.; Nash, R. J. Tetrahedron Lett. 1989, 30, 7261-7264. (b) Burgess, K.; Henderson, I. Tetrahedron Lett. 1990, 31 , 6949-6952. (c) Pearson, W. H.; Hines, J. V. Tetrahedron Lett. 1991, 32, 5513-5516. (d) Choi, S.; Bruce, I.; Fairbanks, A. J.; Fleet, G. W. J.; Jones, A. H.; Nash, R. J.; Fellows, L. E. Tetrahedron Lett,. 1991, 32, 5517-5520. (e) Winchester, B.; Al Daher, S.; Carpenter, N. C.; Cenci di Bello, I.; Choi, S. S.; Fairbanks, A. J.; Fleet, G. W. J. Biochem. J., 1993, 290, 743-749.

5. Gradnig, G.; Berger, A..; Grassberger, V.; Stütz, A. E.; Legler, G. Tetrahedron Lett., 1991, 32, 48894892.

6. $\quad$ Liu, P. S.; Rogers, R. S.; Kang, S. K.; Sunkara, P. S. Tetrahedron Lett., 1991, 32, 5853-5856.

7. (a) Pearson, W. H.; Bergmeier, S. C. J. Org. Chem., 1991, 56, 1976-1978. (b) Pearson, W. H.; Bergmeier, S. C.; Williams, J. P. J. Org. Chem,. 1992, 57, 3977-3987.

8. For conceptually related double cyclizations using aminoepoxides, see: (a) Setoi, H.; Takeno, H.; Hashimoto, M. J. Org. Chem., 1985, 50, 3948-3950. (b) Setoi, H.; Takeno, H. Hashimoto, M. Tetrahedron Lett., 1985, 26, 4617-4290. (c) Kim, Y. G.; Cha, J. K. Tetrahedron Lett., 1989, 30, 57215724.

9. Tejima, S.; Fletcher, H. G. J. Org. Chem., 1963, 28, 2999-3003.

10. Pearson, W. H.; Lin, K.. C. Tetrahedron Lett., 1990, 31, 7571-7574.

11. Loibner, H.; Zbiral, E. Helv. Chim. Acta, 1976, 59, 2100-2113.

12. The two isomers can be differentiated by the ${ }^{1} \mathrm{H}$ coupling constants between $\mathrm{H} 9-\mathrm{H} 9 \mathrm{a}, \mathrm{H} 1-\mathrm{H} 9 \mathrm{a}$ and $\mathrm{H} 1-$ $\mathrm{H} 2$. Neither isomer shows an axial-axial coupling between $\mathrm{H} 9-\mathrm{H} 9 \mathrm{a}$ indicating that these hydrogens are cis and that $\mathrm{H} 9$ is equatorial in both structures. The major isomer 17 shows axial-axial coupling between both $\mathrm{H} 1-\mathrm{H} 9 \mathrm{a}$ and $\mathrm{H} 1-\mathrm{H} 2\left(J_{1,9 \mathrm{a}}=J_{1,2}=9.5 \mathrm{~Hz}\right)$, while the minor isomer 18 shows an axial-equatorial coupling between $\mathrm{H} 1-\mathrm{H} 9 \mathrm{a}\left(J_{1,9 \mathrm{a}}=2.4 \mathrm{~Hz}\right)$, and an equatorial-equatorial coupling between $\mathrm{H} 1-\mathrm{H} 2,\left(J_{1,2}=\right.$ $3.4 \mathrm{~Hz}$ ).

13. Representative spectral data: 9: ${ }^{1} \mathrm{H}$ NMR $\left(\mathrm{D}_{2} \mathrm{O}, 300 \mathrm{MHz}\right) \delta 3.98$ (broad s, $\left.1 \mathrm{H}\right), 3.79$ (broad s, $\left.1 \mathrm{H}\right)$, $3.61(\mathrm{t}, J=9.8 \mathrm{~Hz}, 1 \mathrm{H}), 3.32(\mathrm{dd}, J=3.5,9.8 \mathrm{~Hz}, 1 \mathrm{H}), 2.72(\mathrm{dd}, J=2.9,13.0 \mathrm{~Hz}, 1 \mathrm{H}), 2.65$ (broad d, $J$ $=11.5 \mathrm{~Hz}, 1 \mathrm{H}), 2.16(\mathrm{~d}, J=12.9 \mathrm{~Hz}, 1 \mathrm{H}), 1.94($ broad $\mathrm{t}, J=11.5 \mathrm{~Hz}, 1 \mathrm{H}), 1.6-1.8(\mathrm{~m}, 3 \mathrm{H}), 1.25-1.45$ (m, 2H). ${ }^{13} \mathrm{C} \mathrm{NMR}\left(\mathrm{D}_{2} \mathrm{O}, \mathrm{CDCl}_{3}\right.$ ext std. $\left.90 \mathrm{MHz}, \mathrm{JMOD}\right) \delta 74.44(+), 67.99(+), 67.77(+), 67.21(+)$, $58.92(-), 54.85(-), 29.87(-), 18.48(-) .10:{ }^{1} \mathrm{H}$ NMR $\left(\mathrm{D}_{2} \mathrm{O}, 300 \mathrm{MHz}\right) \delta 3.98(\mathrm{~d}, J=1.6 \mathrm{~Hz}, 1 \mathrm{H}), 3.93$ (ddd, $J=3.2,4.9,11.6 \mathrm{~Hz}, 1 \mathrm{H}), 3.88(\mathrm{dd}, J=1.8,3.7 \mathrm{~Hz}, 1 \mathrm{H}), 3.70(\mathrm{t}, J=3.3 \mathrm{~Hz}, 1 \mathrm{H}$ ), 2.66 (broad d, $J$ $=11.6 \mathrm{~Hz}, 1 \mathrm{H}), 2.49(\mathrm{dd}, J=4.9,10.9 \mathrm{~Hz}, 1 \mathrm{H}), 2.12(\mathrm{t}, J=11.2 \mathrm{~Hz}, 1 \mathrm{H}), 2.09$ (broad s, $1 \mathrm{H}), 1.98(\mathrm{~m}$, $1 \mathrm{H}), 1.71(\mathrm{dt}, J=3.7,12.8 \mathrm{~Hz}, 1 \mathrm{H}), 1.62($ broad d, $J=13.9 \mathrm{~Hz}, 1 \mathrm{H}), 1.41$ (ddd, $J=2.5,3.0,13.5 \mathrm{~Hz}$, $1 \mathrm{H}), 1.31(\mathrm{~m}, 1 \mathrm{H}) .{ }^{13} \mathrm{C} \mathrm{NMR}\left(\mathrm{D}_{2} \mathrm{O}, \mathrm{CDCl}_{3}\right.$ ext std, $\left.90 \mathrm{MHz}\right) \delta 76.72,72.84,72.02,67.35,61.86,58.42$, $57.43,33.78,21.24$. 